\title{
Børnekultur, køn og læreprocesser i børnehave og indskoling
}

Fra et barns forste dag $i$ en institution er det et sandt knoklearbejde at finde en position og social placering i børnegruppen. Den kønsspecifikke opdeling af born begranser udviklingen af legemonstre. Legen er kønsspecifik og resistent over for forandringer $i$ konskulturen.

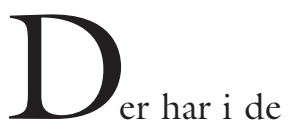

senere år været en fornyet interesse omkring køn og kønnets betydning i pædagogiske debatter knyttet til daginstitutionsområdet og de første år i skolen.

Til forskel fra tidligere diskussioner har det i denne omgang især været drengenes situation, der har været $i$ fokus. Afsættet har været en bredt formuleret bekymring for, at drenge blev klemt i deres identitetsdannelsesproces og ikke mindst i relation til dannelse af en "sund og stabil" kønsidentitet. Feminisering af flere af børnenes opvækst-arenaer ( $\mathrm{fx}$ daginstitutioner, indskoling, fritidsordninger) anføres som væsentlig årsag til, at man nu fra flere sider udtrykker bekymring. Herhjemme har det, måske ikke besynderligt, specielt været mandlige eksperter, der har kastet sig ind i kampen for at styrke drengenes situation (Nordahl 1995 og 1997, Zlotnik 1984 og 1998 samt i fjernsyn og andre medier fx. psykologen Jens Hansen). Også enkelte kvindelige debattører har fremført lignende 
overvejelser (fx antropologen Anne Knudsen).

\section{RETORIKKEN OM DE STAKKELS DRENGE}

At det udgør en væsentlig problemstilling kan umiddelbart argumenteres med henvisning til meldinger fra såvel skole- som daginstitutionssystem om, at der er en uforholdsmæssig stor overvægt af drenge, der defineres som krævende en særlig indsats $i$ form af støttepædagog, ekstraundervisning, henvisning til skolepsykolog, etc.

I Zlotniks terminologi og forståelse udtrykker dette forhold en form for "toppræstation", som dækker over nogle alment udbredte symptomer, der skulle begrunde hans betegnelse "de stakkels drenge" (jf Zlotnik 1984).

“- drenge bliver i barndommen diskrimineret i betydelig højere grad end piger. På den ene side er deres modstandsdygtighed over for både legemlig og psykologisk stress ringere, og samtidig er på den anden side deres symptomer og reaktioner mere alvorlige og dårligere tolereret af omgivelserne. Således optager drengene en uforholdsmæssig stor del af det behandlende og opdragende samfundsapparat. Drenge fanges lettere og hurtigere i en ond cirkel af forhold og omstændigheder, som på selvforstærkende vis øger deres skrøbelighed." (Zlotnik 1984, 113)

En vej ud af denne misere skulle være at rekruttere flere mænd til de pågældende socialiseringsarenaer. Inden for pædagogområdet har der således også fra såvel lokalt hold, specielt på nogle af landets pxdagogseminarier, som centralt, blandt andet $\mathrm{i}$ Socialministeriets regi, været taget initiativer, der sigter mod en mere ligelig kønsmæssig rekruttering af pædagoger og lærere til omsorgs- og undervisningsarbejde.

En bestræbelse som sikkert på mange måder kan være udmærket. Det interessante i denne sammenhæng er imidlertid at af- dække hvilke forståelser af køn i særdeleshed og børn i almindelighed, der gemmer sig bag hovedparten af de senere års bidrag til diskussionen.

Med et begreb hentet fra den amerikanske maskulinitetsforsker Michael Kimmel (1995) synes en stor del af bidragene at skrive sig ind i det "myto-poetiske" univers. Ifølge denne forståelse defineres, blandt andet med henvisning til Robert Bly (1992) som eksempel, en mere eller mindre oprindelig og grundliggende mandlighed, som imidlertid både blandt drenge og mænd af forskellige historiske og samfundsmæssige grunde har haft vanskelige kår for at komme til udfoldelse. En revitalisering af mandligheden skulle i forhold til drenge i børnehave og de tidlige skoleår fremmes ved tilstedeværelsen af mænd, og vel at mærke mænd, der tør stå ved deres maskulinitet. Ud over at fungere som anvendelige identifikationsmodeller for drengene skulle en øget tilstedeværelse af mænd angiveligt også skabe bedre institutionskulturelle betingelser for, at drengene kunne udfolde sig på deres egne præmisser.

Denne tendens til at rette opmærksomheden mod drengenes situation ud fra en bekymring for et tilsyneladende stigende problem synes ikke blot at være et nationalt dansk anliggende, men kan genfindes i den internationale debat. Således har der i de senere år været en livlig debat i England omkring "the underachievement of boys" (Epstein m.fl. 1998, 6). Debbie Epstein og kolleger forsøger at indfange denne tendens i flere engelsksprogede lande gennem identificering af tre diskurser: "the 'poor boys' discourse; the 'failing schools' discourse; and the 'boys will be boys' discourse" (Epstein, m.fl., 1998, 6), hvilket tydeligvis på mange måder formuleres parallelt med den danske debat.

Den stigende opmærksomhed i den britiske debat omkring drengenes faldende skolepræstationer ledsages af interessante forståelsesfigurer. I følge Michèle Cohen er der en lang og sej historisk tradition for at 
"(b)oys' achievement has been attributed to something within - the nature of their intellect - but their failure has been attributed to something external - a pedagogy, methods, texts, teachers. The full significance of this becomes clear when the subject of discourse is girls, for in their case it is their failure which is attributed to something within - usually the nature of their intellect and their success to something external: methods, teachers or particular conditions." (Cohen 1998, 20)

En sådan mytologiseret forståelse af henholdsvis drenge og piger har en form for pendant i Hanne Haavinds undersøgelse af norske mødres opfattelse af og meningstilskrivning i forhold til deres børn afhængigt af kønnet. Haavind fandt, at drengene og drengenes handlinger ofte blev tilskrevet mening via relatering til deres "natur". Når de for eksempel ikke gjorde, hvad der forventedes eller blev ønsket, blev dette forklaret med, at de altid havde været sådan, og at det ikke stod til at ændre. Omvendt blev pigerne oftere beskrevet i "kulturtermer", hvilket betød, at uhensigtsmæssige handlinger og attituder igennem "kultivering"/opdragelse stod til at ændre og udvikles (Haavind 1992).

At denne type af forståelsesfigurer ikke blot er fremherskende blandt voksne, viser Pat Mahony med en henvisning til en nyere engelsk undersøgelse:

"In a project undertaken with 130 14-yearolds, about their attitudes to schoolsubjects and their ambition for the future, it emerged that for many boys, biological accounts of gender were alive and kicking. Being good at (or bad at) different subjects was a matter beyond their control - 'It's in yer brain' as one boy said and there was nothing to be done for some boys for whom it was not 'in yer brain' but to ' $f$ - about'. Girls on the other hand tended to think that if 'you work harder maybe you get to like it and get better at it'.” (Mahony 1998, 48)
I forhold til det tilsyneladende meget ensidige fokus på drengenes situation i den engelske og dele af den danske debat kan det dog bemærkes, at diskussionen herhjemme ikke alene har forholdt sig til drengenes situation. Ofte har det nok så meget været med henvisning til pigernes som til drengenes situation, at man har udviklet forskellige initiativer. Den bagvedliggende forståelse adskiller sig dog ofte ikke fra ovenstående. I flere daginstitutioner og i nogle skoler har man således indført perioder, hvor børnegruppen bliver delt op ud fra køn, således at både piger og drenge får lov til at være "sig selv", og hvor de aktivitetstyper, der lægges op til, er tydeligt kønsmærkede. I enkelte tilfælde afprøves dette ikke blot i forhold til den sociale organisering, men er også fulgt op af kønsdifferentierede indretninger af institutionens lokaler, arten af legetøj, mv.

Den bagvedliggende forståelsesfigur opererer mere eller mindre eksplicit med en antagelse om, at piger har én type af "behov", drenge en anden, ligesom de kvindelige og mandlige pædagoger synes at repræsentere to basalt forskellige logikker.

KRITIK AF ESSENS- OG

REPRODUKTIONSTÆNKNINGEN

I DEBATTEN OM DE STAKKELS DRENGE

Der kan rejses to forskellige, men indbyrdes på kompleks vis forbundne, kritikker af de forestillinger, der præger debatten om kønnets betydning og placering i barndommen.

For det første rammes de i selve opfattelsen af kønskategorien af hele opgøret med essentialismetænkningen, som har stået markant centralt i kvinde- og kønsforskningen i efterhånden en del år. Inden for den del af kønsforskningen, som i de senere år er vokset frem som maskulinitetsforskning, kan udover Michael Kimmel nævnes Bob Connell, der kan stå som repræsentanter for et sådant opgør, i forhold til fx de ovennævnte myto-poetiske og essenstænkende 
tendenser i debatten. I stedet forsøger de at etablere en forståelse af køn, og dermed også maskulinitet(-er), som socialt konstrueret (Connell 1987, 1994 og 1996).

For det andet, og som det jeg vil beskxftige mig med i denne artikel, ligger der mere specifikt i relation til forståelsen af kønskategoriens placering $\mathrm{i}$ barndomslivet en bestemt opfattelse af børn som passive "ofre", der blot reproducerer de mere eller mindre hensigtsmæssige forvaltninger af køn, de voksne præsenterer dem for. Dette billede dækker igen over en dobbeltfigur, idet barnet på den ene side tilskrives en mere eller mindre biologiseret forudprogrammering knyttet til køn: Drenge har nogle behov, nogle fundamentale udtryks- og handleformer, en bestemt psykologi, osv, piger en anden. På den anden side kan fraværet af mænd i omsorgsarbejdet og den anførte feminisering af hele opvækstprocessen underminere denne forudprogrammering, hvorved børnene, såvel pigerne som, og mest "skadevoldende", drengene, frarøves retten og muligheden for at følge det ellers så nydeligt indlagte program.

I det ene moment er biologien, essensen, programmet, behovene, reelt placeret som “aktøren”, i det næste er det de voksne, der godt nok mere eller mindre forvrænget er aktører. Omvendt synes de enkelte og konkrete børn at være opfattet som statister og $\mathrm{i}$ hvert fald tildelt en yderst perifer rolle $\mathrm{i}$ dette kønsspil, hvor de udelukkende tilskrives rollen at reproducere allerede givne mønstre.

Over for dette må udfordringen bestå i at etablere en diskussion af køn i børns lege- og læreprocesser, hvor afsættet tages i en placering af barnet som aktør. Væsentlige eksempler på sådanne bidrag er Barrie Thorne (Thorne 1993), Máirtin Mac An Ghail (Mac An Ghail 1995) samt senest Patricia og Peter Adler (Adler \& Adler 1998).

Især Thorne ekspliciterer nødvendigheden af at forstå kønnets konstruerethed og børnenes egen aktive rolle i disse konstruktionsprocesser. Ydermere tydeliggør hun, at

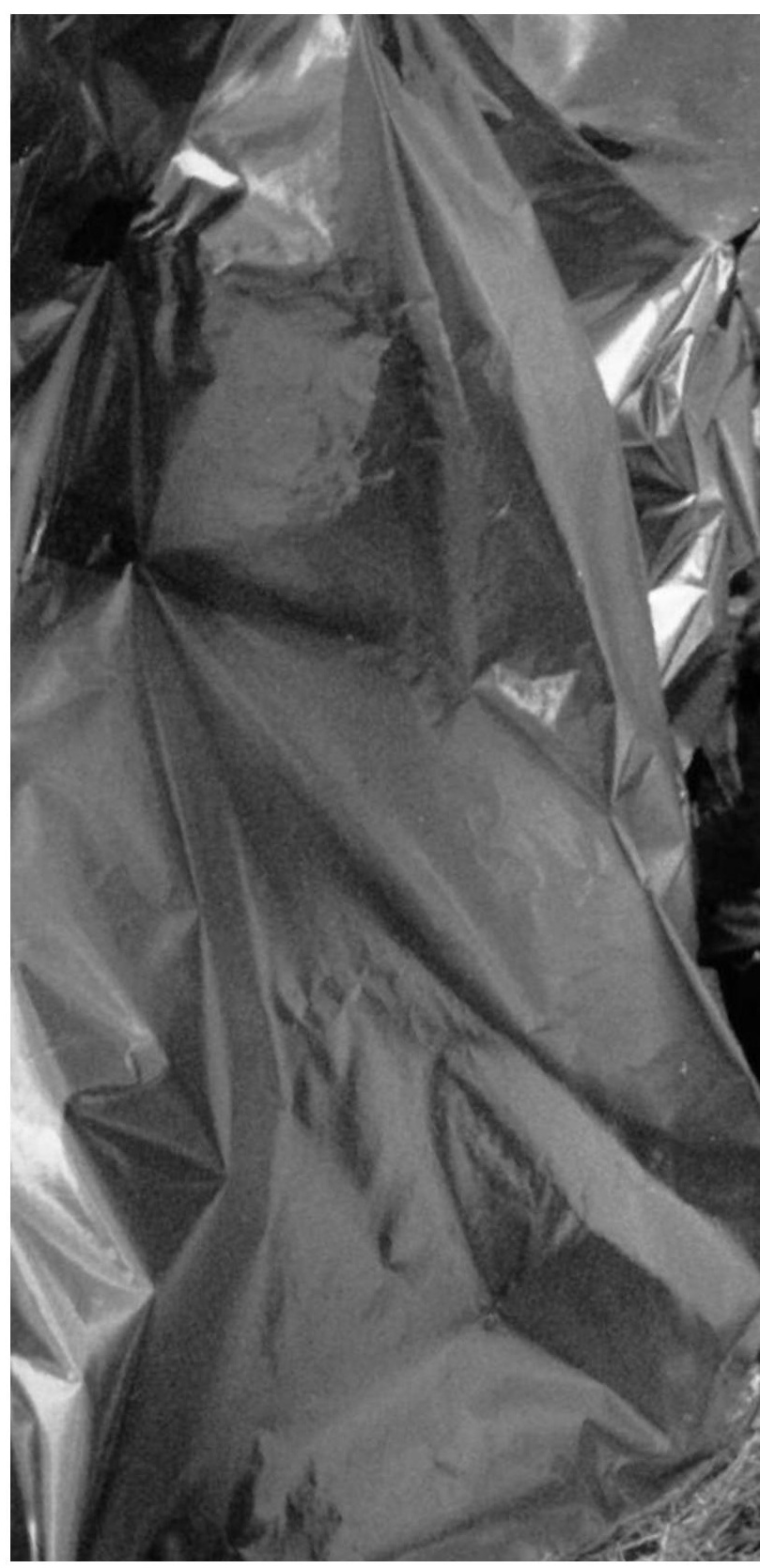




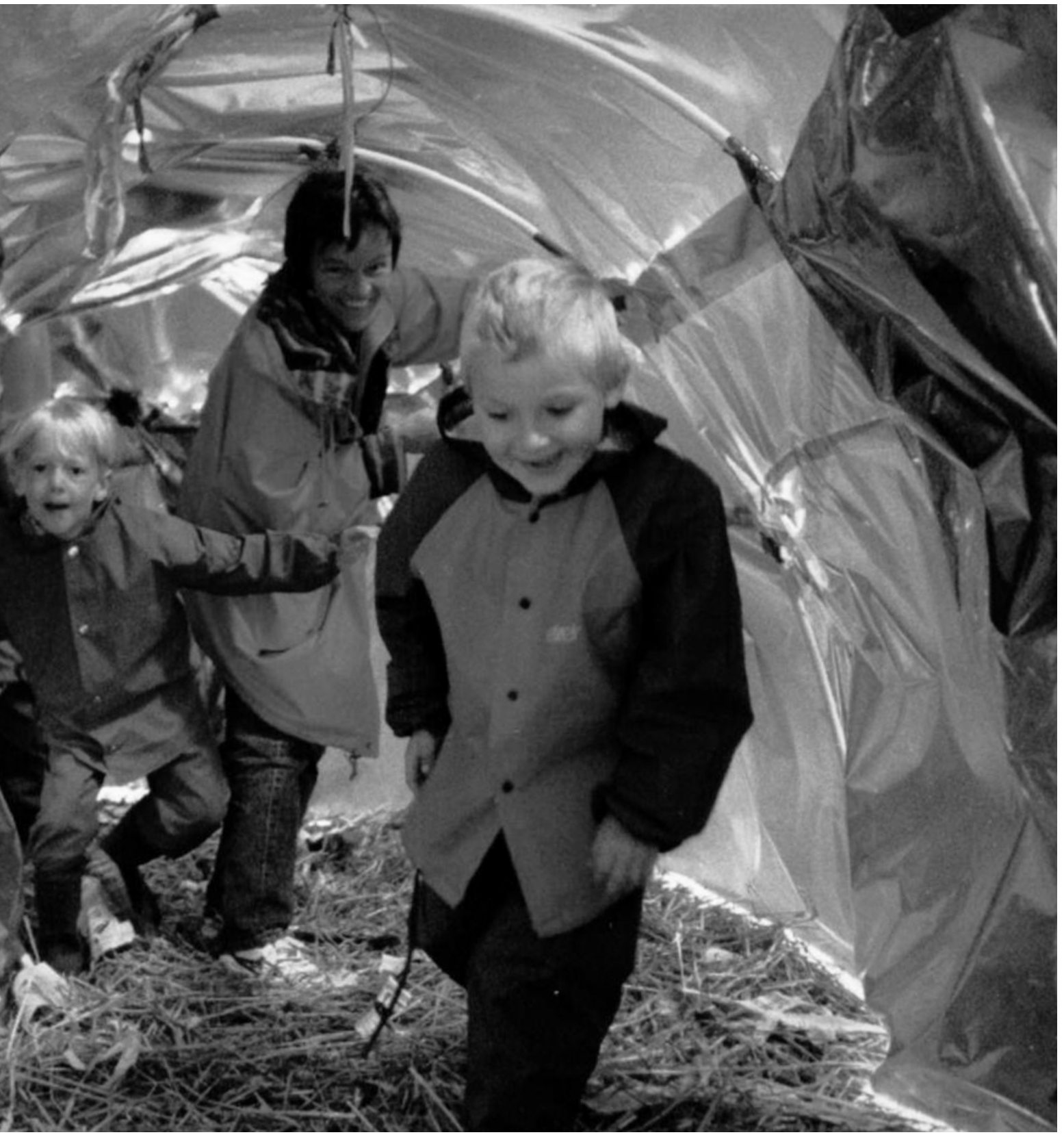


dette ikke alene vedrører et teoretisk og begrebsmæssigt opgør med megen barndomsteori, men nok så væsentligt stiller krav til barndoms(køns-)forskeren om at anlægge et børneperspektiv i sit etnografiske feltarbejde (jf. også Andersen \& Kampmann 1996, Kampmann 1998).

Jeg vil i det følgende med afsæt i eget feltarbejde inden for primært daginstitutionsområdet uddybe og udfolde det perspektiv en sådan tilgang til kønnets betydning i børnehøjde kan føre med sig.

\section{LEG OG RELATIONSDANNELSE SOM BØRNEKULTUR}

Børnekulturbegrebet har i de senere år fået en mere central placering og defineres ofte ud fra tre betydninger: Forstået som kultur for børn, kultur med børn og kultur af børn (se fx Danbolt \& Enerstvedt 1995, 32ff). I denne sammenhæng bliver det især dimensionen kultur af børn, der påkalder sig interesse. For at markere forskellen på denne tilgang og den mere gængse opfattelse af børnekultur, som ofte forbindes med kultur for børn, kaldes det af nogle børns kultur (ibid., 32). I dette ligger også en tydeligere markering af ønsket om at se børn som aktører, som aktive producenter og konstruktører af kultur. Den amerikanske barndomssociolog William Corsaro har med begrebet "interpretive reproduction" (Corsaro 1997, 18) forsøgt at indfange dynamikken i børns kulturproduktion, idet det intenderer at forstå processen som knyttet til både et struktur- og et aktørniveau. Børne- og legeforskeren Brian Sutton-Smith er styret af en tilsvarende intention gennem brugen af begrebet "adaptive potentiation” (Sutton-Smith 1977). Der er tale om reproduktion i og med børnene henter store dele af brændstoffet og inspirationen i en mere eller mindre gennemskuelig voksenverdens kulturelle frembringelser, samtidig med at der ikke blot er tale om en mimetisk overtagelse, men om selvstændige tolkninger, stykvis og delte inddragelser samt ikke mindst nye drejninger og vinklinger, som skaber og afprøver nye betydninger, meninger og orienteringer (se hertil også Mouritsen 1996). Som jeg vil vende tilbage til, får dette også betydning for den forståelse, man tillægger kønskategorien i børns leg og indbyrdes relationsdannelser, hvilket fx den britiske, etnografisk inspirerede, barndomssociolog Alison James beskæftiger sig med i sine empiriske studier (James 1993, 185-200).

Såvel i hendes som i eget observationsarbejde synes barnets søgen efter en position i det børnesociale landskab, som ustandseligt produceres, reproduceres, omdannes, tilslibes, etc, at være et væsentligt omdrejningspunkt for forståelsen af dynamikken i børns kultur ud fra børnenes eget perspektiv.

Fra barnets første dag i institutionen forekommer det at være et sandt knoklearbejde at finde sin position og sociale placering i den sociale struktur børnegruppen udgør. Helt ned i vuggestuealderen kan man iagttage, hvorledes børnene på den ene side er voldsomt optaget af de voksne, samtidig med at de på den anden side bestemt ikke er mindre optaget af de andre børn såvel inden for som på tværs af stuerne.

Orienteringen mod de andre børn indeholder flere momenter, hvoraf de væsentligste synes at være: Etablering af et anvendeligt "kort" over det sociale landskab, afkodning af hvilke "færdselsregler", der gør sig gældende, når man bevæger sig i det sociale landskab samt udviklingen af evnen til rent faktisk at agere i overensstemmelse med disse regler og koder.

I den sammenhæng er anvendelsen af sociale differentieringsmarkører væsentlig for muligheden for at etablere og fastholde det sociale landskab. En af de væsentligste markører er alder, mens en anden tydeligvis bliver køn.

For den pige eller dreng, der netop er startet i børnehaven efter et længere ophold i den nærliggende vuggestue, kan disse bestræbelser udfolde sig i stil med følgende: 
Pia og Michael har det sidste halve års tid i vuggestuen Tusindfryd fået signaler om, hvor store de er: "Du er så stor, at du godt selv kan tage tøj på, mens de små jo ikke kan finde ud af det endnu”, “du er jo så stor, at du godt kan spise selv, mens jeg er nødt til at hjælpe de små imens", "du er så stor, at du godt kan vente lidt, mens jeg lige trøster en af de små, for de kan jo ikke så godt vente", etc., etc. "Du er faktisk så stor, at du er blevet for stor til at gå her i vuggestuen, ja, du er nu så stor, at du er blevet et børnehavebarn!" Man kan næsten se for sig, hvordan Pia eller Michael må opfatte sig selv i stil med en oppustet Michelin-figur, der, hvis de ikke skynder sig lidt med at komme ud af det her sted, når at blive så store, at de knap kan komme ud af døren. Og det er faktisk tydeligvis også med denne konstruerede selvforståelse, at de dukker op i børnehaven Blomsterengen. Ikke sjældent vil man kunne se, hvordan Pia og Michael styrter direkte hen til "de andre store", hvilket i det nye sociale landskab, børnegruppen i børnehaven udgør, betyder de 5-6 årige. Umiddelbart vil disse to 3 årige måske blive modtaget med åbne arme, for de store børnehavebørn synes ind imellem, det er ret fedt at have nogle af de små med i legen, for det kan tit være svært at få nogle til at indtage rollen som hund, baby eller sågar dukke. Så Pia eller Michael får uden problemer lov til at være med, hvis blot de er baby, og i øvrigt skal babyen sove, så værsgo og læg dig ned og forhold dig fuldstændig i ro. Hvis Pia eller Michael så reagerer ud fra den position, de indtog $\mathrm{i}$ vuggestuen som dronning og konge over henholdsvis Radisestuen og Tumlingerne, hvor de var vant til en noget mere aktiv og central rolle i legeforløbene, kommer den sociale markør 'alder' straks frem til overfladen: Hvis ikke de vil indordne sig, kan de ikke være med, for de er jo en af de små - eller mere raffineret: "Det her er ikke for sovebørnene". Begrundelser og benævnelser omkring inddragelse og udelukkelse fra de lege- og relationsgrupper, der etablerer sig indenfor og udgør subkulturelle delelementer i det samlede børnesociale landskab, er således ofte knyttet til aldersmarkøren. For Pia og Michael betyder det et hårdt slid $\mathrm{i}$ form af dels at finde $\mathrm{ud}$ af, hvordan de forskellige aldersforankrede opdelinger af børnegruppen fungerer i denne nye sammenhæng, og ikke mindst skal de omdefinere deres egen position i forhold til dette nye landskab. Over night er de degraderet fra øverstbefalende til usle vandbærere, hvilket igen betyder, at de i forsøget på at etablere relationer til de andre børn må orientere sig i forhold til gruppen af "de andre små".

\section{KØNSKATEGORIEN I BØRNS LEGE-} OG RELATIONSKULTUR

Tilsvarende udgør kategorien køn en relativ stabil social markør i differentieringen og specificeringen af det sociale landskab. Inddragelse og udelukkelse fra en given legegruppe ledsages ikke sjældent med en begrundelse knyttet til køn: “Du må ikke være med, det er kun for drenge" eller "nej, vi vil ikke have nogle af drengene med, for ..." synes at være fuldt valide opdelingskriterier børnene imellem. I de mere raffinerede udgaver af dette kan der endda etableres en nærmest drillende leg med vekslingen mellem inddragelse og udelukkelse, som når to piger inddrager en jævnaldrende dreng i deres leg, for så i sammenhæng med tildelingen af far-rollen i næste moment at ekskludere ham fra legen (i hvert fald den aktivt handlende del af den) i form af at sende ham på arbejde, hvilket foregår ved, at han måske får besked om at tage den trehjulede og cykle om bag legehuset og i øvrigt blive dér.

Alder, køn og andre markører bliver således en væsentlig del af børnenes etablering af et landskab og dermed også et væsentligt element i det enkelte barns tilkæmpen sig en position.

Tilknytningen til bestemte andre børn er under konstant forhandling, hvor det en- 


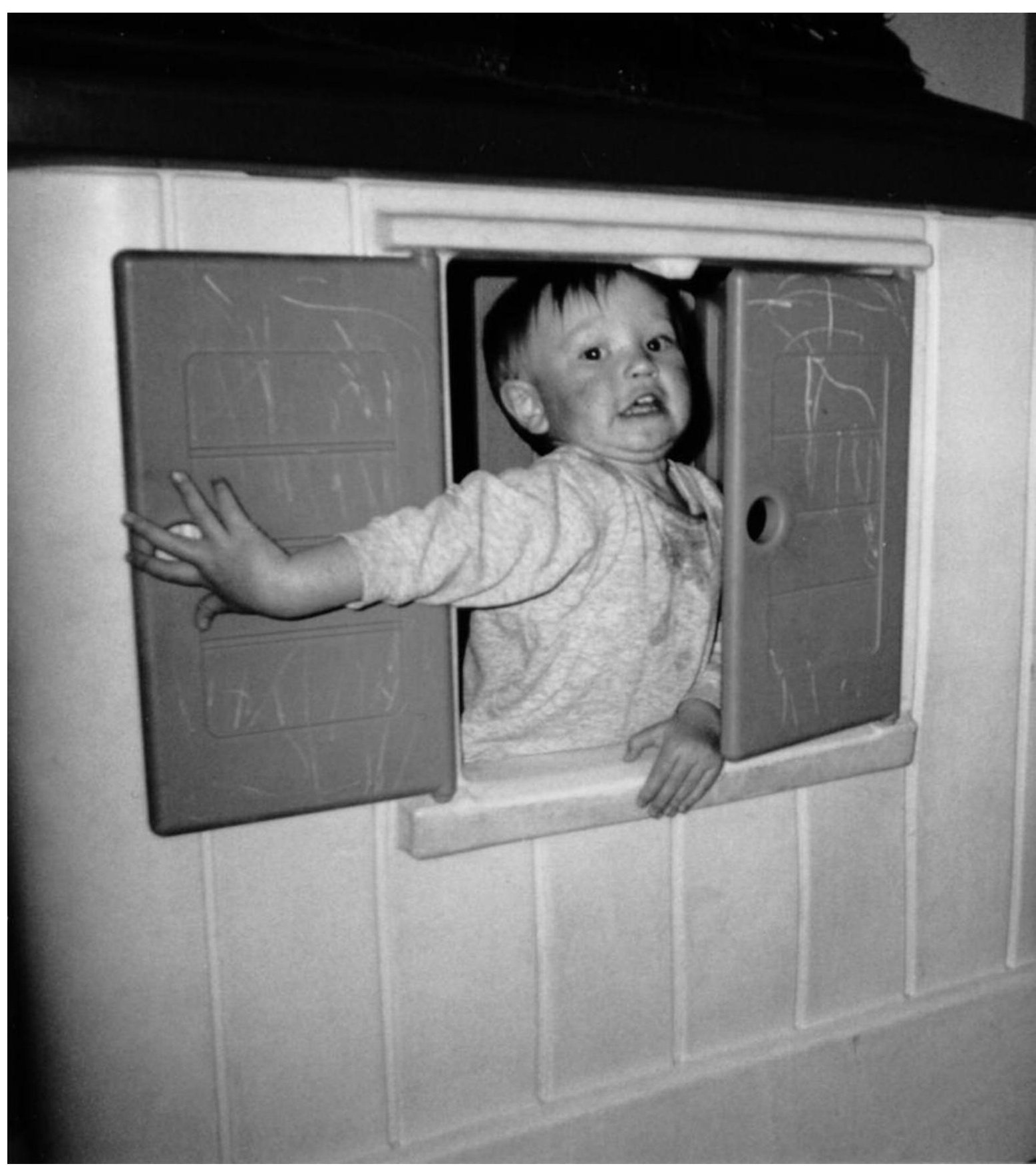

Foto venligst udlaint af vuggestuen "Den gule prik" 


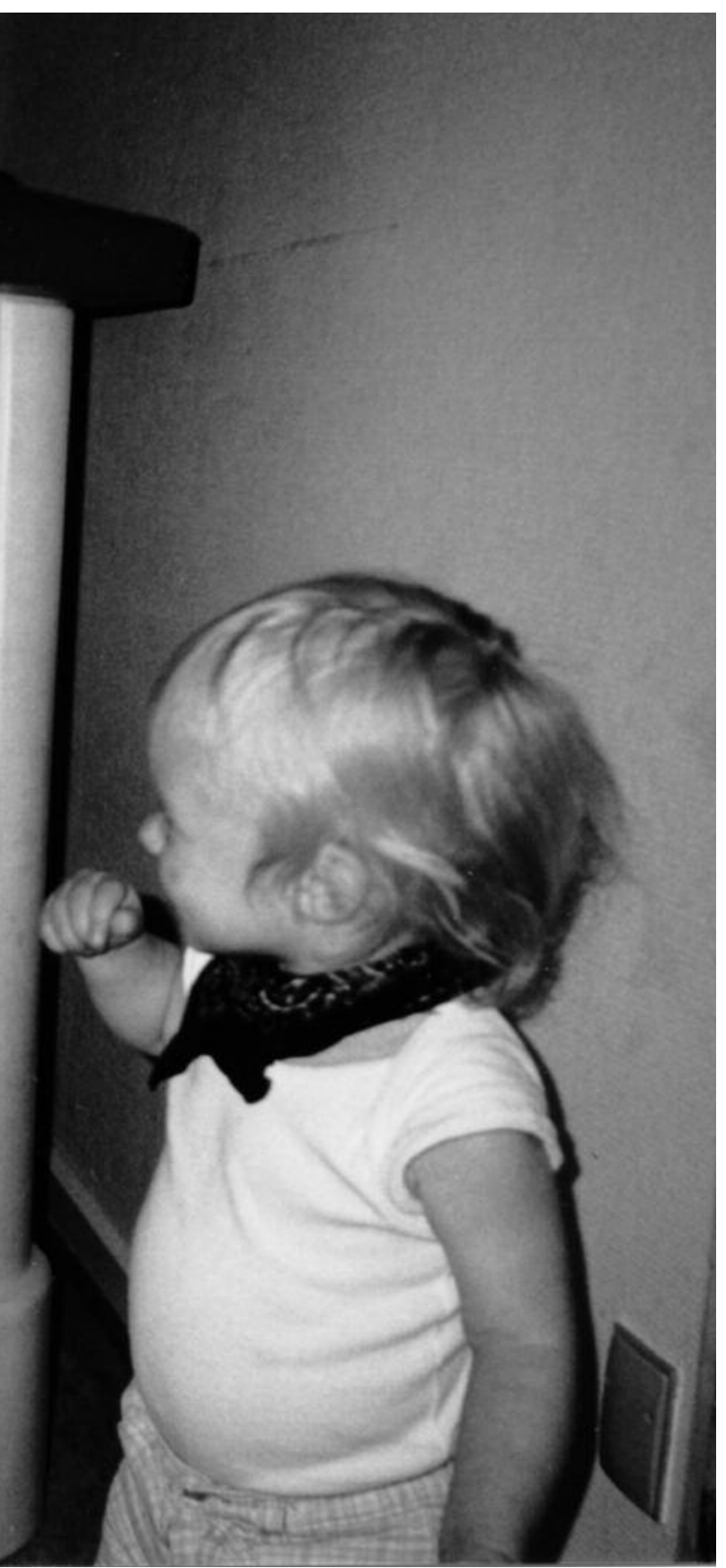

kelte barns forhandlingskompetence er af afgørende betydning for dets mulighed for at blive en del af en eller flere mere eller mindre fasttømrede gruppedannelser. Allerede i vuggestuen kan ses rudimenter af sådanne faste relationsdannelser, hvilket yderligere udvikles i løbet af børnehavetiden og ind i skolen. I og med køn er en af de væsentlige markører af forskellighed og nærhed, danner det også afsæt for ofte rimeligt fast forankrede kønsopdelte relationsdannelser og til dels legegrupper. Såvel James (1993) som Adler og Adler (1998) viser igennem deres materiale, som i begge tilfælde involverer børn i alderen fra 4-5 årige op til 9-11 årige, at der sker en udvikling over tid, tilsyneladende knyttet til børnenes alder og den sociale sammenhæng. For de mindste børn i deres materiale finder de ikke endnu så fast en forankring af de kønsopdelte relationsdannelser, hvilket til gengæld sætter sig massivt og nærmest rigidt igennem i 6-8 års-alderen, mens det for de xldste i deres materiale så småt begynder at antage nye former igennem en gensidig interesse $i$ at nærme sig det andet køn, nu med klare følelsesmæssige afprøvninger som væsentlig ingrediens.

I eget materiale (Andersen \& Kampmann 1996, Kampmann 1993) synes der både at være klar overensstemmelse, men på nogle punkter også uoverensstemmelse, i forhold til ovenstående. I den danske institutionssammenhæng, hvor vores undersøgelser er foregået, synes der på et tidligere tidspunkt at være klare markeringer af lege- og relationsgruppernes kønnede karakter, samtidig med at vi også kan se mange eksempler på legerelationer, hvor begge køn er repræsenterede. En tolkning kunne være, at dansk institutionspædagogisk tradition igennem nogle år har prioriteret børns leg, og dermed måske givet rum for at børn i danske institutioner i en tidligere alder får mulighed for at skabe og afprøve sociale relationer i deres eget børnekulturelle univers. Dette kan i og for sig bidrage til forklaring af begge disse mønstre. På den 
ene side tidligere erfaringer med egne forhandlinger om inddragelse og udelukkelse af deres sociale relationer og legerum, hvor køn tidligt bliver brugt som markør, samtidig med at de på den anden side måske netop gennem disse tidlige erfaringer også har mulighed for i eget tempo at afprøve betingelser for det Thorne kalder "bordercrossing" (Thorne 1993, 111ff).

Under alle omstændigheder udgør den relativt bastante kønsspecifikke opdeling i børnenes venskabs- og legegrupper (i hvert fald i en væsentlig del af deres institutionshverdag) en ramme for udvikling af legemønstre, hvor legens kulturelle koder, reguleringer, rutiner og ritualer synes at være overraskende kønsspecifikke og irriterende resistente over for forandringer i kønskulturen i øvrigt. Fremstillingen af det mandlige og det kvindelige i børnenes legeunivers fremstår som yderst konservativt og går umiddelbart klart bag om de forandringer, der i den øvrige samfundsmæssige kontekst ideologisk og praktisk er sket omkring kønsarbejdsdelingen. I forlængelse af dette er det påfaldende, at vi i vores materiale fra starten af og op igennem 90'erne, i øvrigt helt parrallelt til både Thornes og James' undersøgelser, ligeledes fra starten af 90'erne finder de samme kønsspecifikke legekulturelle mønstre, som allerede Berentzen (1969) og Lever (1976) fandt i deres materiale fra slutningen af 60 'erne og starten af 70'erne: Drenge leger i større, ofte aldersbaserede grupper, med en relativ diffus afgrænsning, med både fysisk og tematisk orientering ud mod det offentlige rum, ofte centreret omkring kampen mellem det gode og det onde, baseret på præstationsog konkurrencemomenter samt sags- og funktionsorienteret. Pigerne leger i mindre mere private og klart afgrænsede, men ikke nødvendigvis aldershomogene grupper, tematisk orienterede mod det hverdagslige og erfaringsnære, centreret omkring personernes udvekslinger og forholden sig til hinanden, baseret på overensstemmelse/ uoverensstemmelse og relationsorientering (for en uddybelse se Andersen \& Kampmann 1991). Beskrivelser som i øvrigt også langt hen ad vejen stemmer overens med Harriet Bjerrum Nielsen og Monica Rudbergs arbejder fra 80'erne (Nielsen \& Rudberg 1988 og 1989).

Gennem opretholdelsen af kønnet som social markør i etableringen af de sociale relationer skabes også relativt gennemgribende forskellige legekulturelle koder de to køn imellem, hvilket følgende episode kan illustrere:

To piger omkring $41 / 2$ år leger med et dukkehus på gulvet inde på Blå stue. De har forhandlet sig frem til et fælles legeforestillingsunivers samt fordeling af roller. De er henholdsvis mor og datter, der går i skole og skal lave lektier, hvilket hun absolut ikke har lyst til. Dette udløser morens vrede, hun skælder ud og forlanger, at datteren går i gang med lektierne. Datteren påvirkes af moderens bebrejdelser og accepterer, at hun skal lave lektier, hvilket straks formilder moderen, som bliver sød og venlig over for datteren, som tilsvarende bliver i bedre humør, osv. Undervejs i disse udvekslinger mellem mor og datter kommer to drenge (også begge omkring 41/2 år) hen til pigerne og spørger om, de må være med. Den pige, der er moderen, og som tydeligvis er "legeleder", reagerer positivt på forespørgslen og bestemmer, at den ene af drengene er baby, mens den anden er lillebroder. Det accepterer drengene, som sætter sig ved siden af pigerne, uden i øvrigt at foretage sig noget. Der går lidt tid, hvor pigerne fortsætter deres dialog, stadig uden at drengene er begyndt at agere. Så stopper moderen op, går så at sige ud af sin rolle og indtager i stedet positionen som instruktør: "Skal vi ikke sige, at babyen skulle sove, men det ville han ikke, og så bliver moderen vred!?" siger hun henvendt til den dreng, der skulle indtage babyrollen. Det er han straks med på, og da pigen igen indtager moderrollen og begynder at give babyen ordrer om, at han skal sove, nægter han højlydt med en tydelig fræk attitude at ef- 
terkomme moderens befaling. Moderen skælder mere og mere ud, hvilket blot bevirker, at babyen tilsvarende bliver mere og mere fræk og genstridig. På et tidspunkt markerer moderen et "break" og indtager igen rollen som instruktør: "Når moderen skælder ud, bliver babyen ked af det!" "Nåeh" siger drengen i en blanding af forvirring og afklaring, hvorefter de begge igen kaster sig ind på "scenen" i hver deres rolle. Da moderen igen begynder at skælde ud, bliver baby straks ked af det. Han græder og græder, hvorefter moderen ændrer attitude og begynder at trøste den grædende baby - som imidlertid blot fortsætter med at græde og græde. Efter at dette har stået på i endnu et stykke tid, laver moderen igen et break: "Når moderen trøster baby, bliver baby jo glad igen" erklærer hun, denne gang tydeligvis en kende irriteret og utålmodig. Drengen siger igen blot "nåeh", men denne tydeligvis mere forvirret end afklaret, som om han på sin side ikke kan forstå, hvorfor instruktøren ikke kan bestemme sig for, om han skal det ene eller det andet.

På dette tidspunkt er det åbenbart blevet for meget eller for lidt for den anden dreng. Han tager godt fat i dukkehuset og ryster det rimeligt voldsomt, mens han udbryder: "Pludselig blev det et forfærdeligt uvejr, det tordnede og lynede, og lynet slog lige ned i huset." Det var tilsyneladende en legehandling, der gav den dreng, der hidtil havde forsøgt at agere baby, en klar mulighed for at handle spontant i tråd med udspillet. Han greb nogle klodser fra gulvet og førte dem i fuld fart hen mod dukkehuset. "Babuu, babuu, her kommer brandmændene for at slukke ildebranden." I løbet af øjeblikke havde de to drenge fået omdefineret legerummet til at være en kæmpe ildebrand med tilhørende brandslukningsmanøvrer og de to som hovedrolleindehavere i denne funktionsudøvelse. Denne gang synes pigerne forvirrede, og den ene forsøgte at bringe legen tilbage på sporet: "Nej, nej, det blev overhovedet ikke uvejr, huset brænder slet ikke, babyen var faktisk lige ved at falde i søvn!”

Såvel pigerne som drengene kan i denne episode siges at bearbejde og udvikle væsentlige sociale og kulturelle kompetencer: Pigerne den seismografisk fintmærkende lytten sig ind på det personlige samspil, hvor svingninger i følelsesmæssige udtryk udgør voldsomme handlingsforløb, hvilket drengene tilsyneladende ofte har sværere ved at opfange. Derimod er drengene i denne og andre lege lige så ofte $\mathrm{i}$ stand til at opbygge fælles forestillingsuniverser, hvor de i deres optagethed af ydre handlingsforløb er nok så afhængige af gensidig opmærksomhed omkring hvilke nye handlingstiltag, der kan udgøre en passende fastholdelse og videreudvikling af legeforløbet. Pigernes kompetence i det relationsorienterede og drengenes i det sagsorienterede udtrykkes tydeligt i dette eksempel.

Det interessante i eksemplet er ikke en vurdering af kvaliteten i de to typer legekoder. De kræver begge højt udviklede sociale og kulturelle legekompetencer.

Det kunne snarere påkalde sig overvejelse, om de kønsspecifike legemønstre, som illustreres igennem eksemplet, er ligeså udbredte som tidligere samt hvilken forklaring, der kan knyttes til dette, hvis ikke det myto-poetiske standpunkt blot skal bekræftes.

\section{KøN TIL FORHANDLING}

At de forskellige legekulturelle koder som i ovenstående eksempel ofte gav problemer, selv der hvor børnene ønskede at etablere Thornes "border-crossing", er ikke ensbetydende med, at det ikke ofte forsøgtes og også lykkedes. Typisk i tilfælde hvor det var en enkelt pige eller dreng, der bevægede sig ind i det andet køns legekulturelle rum, udvisende tydelige evner til at gebærde sig også i dette landskab. Som også andre undersøgelser påpeger, synes det især at være nogle af pigerne, der er i stand til at lave denne form for afkodning eller oversættel- 
sesarbejde. Det kunne imidlertid også forekomme i tilfælde, hvor der var flere piger og flere drenge, der gensidigt ønskede at lege med hinanden, men i sådanne tilfælde ofte krævende kortere eller længerevarende forhandlingsforløb, før en fælles legedagsorden reelt blev fulgt.

Sideløbende med at der etableres bevidste markeringer af forskellighed forhandles der således også ustandselig om overskridelser og overlap, om nye betydninger og udkast.

Selvom der således synes at være en voldsom træghed i forandringen i den måde børnene konstruerer kønsspecifikke legekoder, og dermed også etablerer to relativt selvstændige erfaringsrum, med de identitetsdannende virkninger dette måtte have, er det vigtigt at påpege, at der i dette ikke med nødvendighed alene ligger en bekræftelse på reproduktion af kendte måder at forvalte køn på.

For grundlæggende i børnenes relationsdannelser, deres markering af ligheder og forskelle, deres forhandlinger om grænsedragninger, inddragelser og udelukkelser, ligger nogle fælles etableringer af forhandlingskompetence, som igen baserer sig på perspektivskift, på aflæsning af koder og handlemønstre, på gensidig indlevelse og empati. På samme tid som køn for børnene udgør en væsentlig forskelsmarkør, etableres der omkring køn tilsyneladende allerede fra omkring 6 års-alderen tillige et spændingsfelt. Thorne (1993) og mere udfoldet Adler og Adler (1998) viser, hvordan børnene allerede fra de mindste klasser i skolen ikke kun bruger kønsmarkeringen til at marginalisere sig $\mathrm{i}$ forhold til det andet køns univers, men tillige er voldsomt orienteret mod at tilnærme sig og reflektere over indholdet og meningen i dette "andet". I forbindelse med deres længerevarende feltstudie gennemførte Adler og Adler en mængde formelle og uformelle samtaler med piger og drenge, og deres materiale viser, at der både blandt piger og drenge er en voldsomt udviklet sensitivitet og gensi- dig indlevelse, med etablering af rimeligt sofistikerede refleksioner over hvordan man oplever det andet køn, hvordan man tror, det andet køn oplever en selv, hvordan man selv oplever sig i sin tilnærmning til det andet køn, hvordan der inden for ens eget køn er kulturelle koder, der fordrer bestemte typer af adfærd over for det andet køn, hvis ikke man skal risikere at miste status og position inden for sin egen kammeratskabsgruppe, osv. Samtidig med at børnene giver udtryk for den voldsomme interesse i det andet køn, er netop de første skoleår præget af en markant markering af, at det er vigtigt at involvere sig i legeforløb inden for "egne rækker".

Fra den sene vuggestuealder, ind i børnehaven og stærkt udfoldet i de første skoleår synes børnenes identitetsarbejde blandt andre differentieringsmarkører at orientere sig stærkt mod betydningen af køn. Søgningen efter at finde ud af hvad det vil sige at være "mig" knyttes tydeligvis blandt andet til afprøvninger af, hvad det vil sige at være pige henholdsvis dreng. Gennem afgrænsninger og overskridelser af grænser udgør det børnekulturelle lege- og relationsrum også et rum for bearbejdning af identitetserfaringer.

På den ene side kan den tilsyneladende konservatisme i de etablerede kønsspecifikke legekoder signalere en uforanderlighed i måden børn tilegner sig og forvalter køn på, hvilket blandt andet kan tilskrives børnekulturens egendynamik, der fordrer opdelinger, grænsedragninger osv. Som nævnt indebærer dette ikke mindst $\mathrm{i}$ indskolingsårene et pres børnene indbyrdes med hensyn til overholdelse af ganske stereotype forvaltninger og udfoldelser af køn, hvor afvigelser risikerer at blive mødt med social mærkning og lav værditilskrivning.

På den anden side er det lige så tydeligt, at rammerne for hvad henholdsvis piger og drenge kan tillade sig uden at forbryde sig mod de børnekulturelle normer og koder til stadighed udfordres og forhandles. 


\section{VOKSNES PLACERING I BØRNENES KULTURELLE UNIVERS}

Ud fra dette perspektiv synes den generationsvise reproduktion af kønsopfattelser og kønsstereotypier nok så meget at være noget der formidles fra den ene generation af børn til den næste, som det synes at være direkte formidlet fra tilstedeværende voksne. Man kan derfor betvivle betydningen af mere målrettede vokseninitierede kønspædagogiske tiltag.

Dette er imidlertid ikke ensbetydende med, at de voksne er uden betydning. Hvis man tager afsæt i Corsaros begreb om interpretive reproduction eller Sutton-Smiths begreb om adaptive potentiation er børnenes egenbearbejdning af kønskulturelle koder jo et eller andet sted også en aktiv bearbejdning af voksenverdenens kønskulturelle koder, således som de symbolsk og handlingsmæssigt kommer til udtryk. De stereotypier, som det tidligere nævnte eksempel til overflod illustrerede den stadige eksistens af, behøver ikke at være udtryk for essenstænkningens berettigelse. Med afsæt i de refererede engelske og norske undersøgelser af de voksnes opfattelse af og tilgang til henholdsvis piger og drenge kan den kønsværditilskrivning, der ligger i dette, langt hen ad vejen forstås som bidragende til en fastholdelse af de traditionelle kønsmønstre. Også ud fra eget materiale, der omhandler det pædagogiske arbejde i daginstitutioner, kan der findes tilsvarende mønstre i den måde de voksne relaterer sig til børnene afhængigt af køn. Lidt prøvende kunne man tale om en dobbelt ambivalens i reaktionen på børnene.

Pigerne bliver på den ene side ofte mødt med en bekræftende forventning om ansvarlighed. Når det brænder på i hverdagen, er det ofte pigernes ansvarlighed, der appelleres til, mens drengenes ansvarlighed kun fastholdes af de voksne, når der er tid og overskud til at følge "projektet" til dørs.

På den anden side er den større tillid og forventning til pigernes ansvarlighed og socialitet, til "kultiveringsmuligheden", ikke nødvendigvis sammenhængende med en egentlig respekt og værdsættelse af pigernes børnekulturelle kvaliteter. Pigernes tættere indbyrdes relationer kan let udløse den voksnes irritation og misbilligelse og påkalde sig benævnelser som "finket", "strengt" og "stridt" over for de udelukkede. Spørgsmålet er groft sagt, om pigerne på den ene side fastholdes $\mathrm{i}$ en stereotyp kønstilskrivning, samtidig med at disse kvaliteter på den anden side ikke tilskrives egentlig værdi i de voksnes måde at "møde" og "genkende" pigerne.

Omvendt udsættes drengene ofte for "nedmuntring" i forhold til deres legekulturelle koder. Det er drengene, der angives at være besværlige, anstrengende, osv, samtidig med at det signaleres, at det på trods af uhensigtsmæssigheden er "skægt", "spændende", osv. På den ene side irettesættes drengene oftere end pigerne, på den anden side modtager de under overfladen en stor grad af anerkendelse for deres brud med institutionens hverdagsrutiner.

De kulturelle overleveringer, der foregår fra voksne omkring køn, kan på denne måde formentlig langt hen ad vejen siges at bekræfte og fastholde gammelkendte kønsmønstre fremfor at udgøre nuancerende, åbnende og søgende indspil til de yderligere forhandlinger omkring kønnets betydning, som foregår i børnenes egne rum.

Hvis man forestiller sig, at voksne burde have en indvirkning på retningen i disse bearbejdninger, kunne det primært være i form af at stille så bredt et spekter af kvindeligheder og mandligheder til skue for børn, således at deres fortsatte afprøvninger af kønnets betydning og mening inden for lege- og relationsuniversets domæne inspireres af et mere mangfoldigt input.

Det kan således godt være rigtigt at såvel piger som drenge kunne have fornøjelse af flere mænd i daginstitutioner og skole. Men ikke i form af entydige og regressivt kønnede identifikationsfigurer, således som signalet om tilbagekomsten af den "rigtige mand" kunne tolkes. Der må snarere være 
tale om tilstedeværelse af mænd og kvinder, der gennem deres forskellige måder at forvalte køn stiller et "inspirationsmateriale" til rådighed, således at børnenes egne bearbejdninger og afprøvninger af kønnenes grænser ikke unødigt fastlåses i stereotypier, men tværtimod tilskyndes til at udvide og flytte grænserne for det mulige og det tilladelige.

Når piger tilsyneladende i højere grad end drenge har været i stand til at etablere en rummelighed i forhold til hvad det vil sige at være pige, kunne et bidrag til dette have været, at piger i løbet af de sidste 20 år netop ikke er blevet præsenteret for et entydigt kvindebillede i den voksenkultur, de prøver sig af i forhold til. De har på den ene side oplevet den markante tilstedeværelse af kvinder i omsorgsudøvelsen, men samtidig i form af et spektrum af kvindeligheder, der har styrket en mangfoldighed i afprøvningerne inden for deres egne kulturelle søgeprocesser. Parallelt med dette kunne det være en målsætning ikke blot at genindføre maskulinitet i børns univers som en entydig og endimensional størrelse, men som et tilsvarende bredt udbud af maskuliniteter.

\section{LITTERATUR}

- Adler, Patricia A. \& Peter Adler (1998): Peer Power. Preadolescent, Culture and Identity. Rutgers University Press, London.

- Andersen, Peter Ø. \& Jan Kampmann (1991):

Kønnets betydning for borns interaktion og relationsdannelse. Institut for Pædagogik, Københavns Universitet, Forskningsnoter nr. 8.

- Andersen, Peter Ø. \& Jan Kampmann (1996):

Børns legekultur. Munksgaard, København.

- Berentzen, Sigurd (1969): Kjønnskontrasten $i$ barns lek. Bergen.

- Bly, Robert (1992): Jern-Hans. En bog om mand. Lindhardt \& Ringhof, Viborg.

- Cohen, M. (1998): 'A habit of healthy idleness': boys' underachievement in historic perspective, in Epstein, m.fl. (1998).

. Connell, Robert W. (1987): Gender \& Power.

Polity Press, Cambridge.
- Connell, Robert W. (1994): Masculinities. Polity Press, Cambridge.

. Connell, Robert W. (1996): Teaching the Boys:

New Research on Masculinity, and Gender Strategies for Schools, in Teacher College Record, vol. 98, nr. 2.

. Corsaro, William A. (1997): The Sociology of

Childhood. Pine Forge Press, London.

- Danbolt, Gunnar \& Åse Enerstvedt (1995): Når voksenkultur og barns kultur møtes. Norsk Kulturråd, rapport nr. 2, Oslo.

- Epstein, D., Elwood, J, Hey, V. \& Maw, J. (Eds.)(1998): Failing Boys? Issues in Gender and Achievement. Open University Press, Buckingham. - James, Allison (1993): Childhood Identities. Edinburgh University Press, Edinburgh.

- Kampmann, Jan (1993): Kønnets betydning i småbørns relationsdannelse, in Anne Maj Nielsen, m.fl. (red): Køn i forandring. Forlaget Hyldespjæt, København.

- Kampmann, Jan (1998): Børneperspektiv og børn som informanter. Børnerådet, Arbejdsnotat, nr. 1, Socialministeriet, København.

- Kimmel, Michael (1995): Menns rettigheder, menns myter og menns lyter -maskulinitetsbestræbelser i dagens Nord-amerika, in Nyt om Kvinneforskning, årgang 19, Oslo.

- Lever, J. (1976): Sex differences in the games children play, in Social Problems, 1976/4.

- Mac An Ghaill, Máirtin. (1995): The Making of Men. Masculinities, sexualities and schooling. Open University Press, Buckingham.

- Mahony, P. (1998): Girls will be girls and boys will be first, in Epstein, m.fl. (1998).

- Mouritsen, Flemming (1996): Legekultur. Essays om børnekultur, leg og fortælling. Odense Universitetsforlag, Odense.

- Nielsen, Harriet Bjerrum \& Monica Rudberg (1988): Hur flickor blir flickor och pojkar blir pojkar, in Kvinnovetanskapligt tidsskrift, 1988/3.

- Nielsen, Harriet Bjerrum \& Monica Rudberg (1989): Historien om jenter og gutter. Universitetsforlaget, Oslo.

- Nordahl, Bertill (1995): Tarzan $i$ damejunglen. Forlaget Nielsens, København.

- Nordahl, Bertill (1997): Pigerne \& drengene - ni samtaler om kønnets betydning. Forlaget Nielsens, København.

- Sutton-Smith, Brian (1977): Play as adaptive potentiation, in P. Stevens (ed.): Studies in the Antbropology of Play. Leisure Press, New York.

- Thorne, Barrie (1993): Gender Play. Girls and Boys in School. Open University Press, Buckingham. 
- Zlotnik, Gideon (1984): De stakkels drenge. Konsforskelle i barndommen. Hans Reitzels Forlag,

København.

- Zlotnik, Gideon (1998): De stakkels børn. Den psykologiske lavalder og den daglige hjernevask. Forlaget Nielsens, København.

\section{SUMMARY}

The article discusses the rhetoric of "the poor boys" and the "feminisation" of day-care institutions and primary schools. Referring to international as well as the authors own research, some of the common understandings are questioned. Instead of seeing "essence" as the explanation for the existence of gender- stereotypes among children, focus is on children's never ending negotiations on gender. Attention is drawn to children as agents and to children's cultural constructions concerning the meaning and impact of gender.

Gender appears to be of central importance to children's attempt to establish social boundaries, collective and individual identities through play and social interaction. Qualified input from adults to these negotiations seems to be a diversity of masculinities and femininities, rather than conforming to a kind of "Tarzan and Jane"-dichotomy.

Jan Kampmann, lektor, Institut for Uddannelsesforskning, Roskilde Universitetscenter 